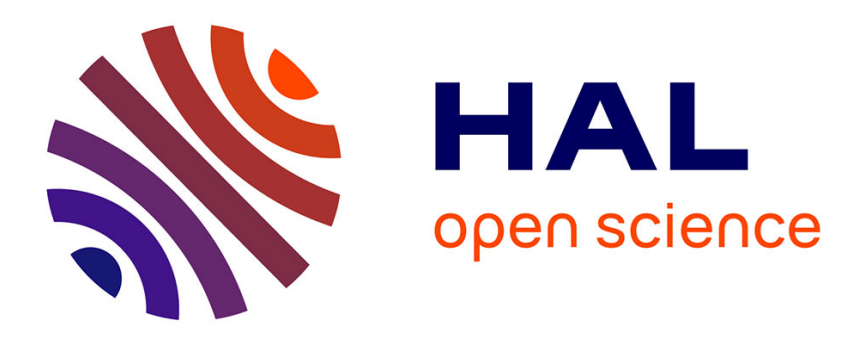

\title{
Effect of testing conditions and doping on superplastic creep of alumina
}

P. Gruffel, P. Carry, A. Mocellin

\section{To cite this version:}

P. Gruffel, P. Carry, A. Mocellin. Effect of testing conditions and doping on superplastic creep of alumina. Revue de Physique Appliquée, 1988, 23 (4), pp.716-716. 10.1051/rphysap:01988002304071600 . jpa-00245871

\section{HAL Id: jpa-00245871 https://hal.science/jpa-00245871}

Submitted on 1 Jan 1988

HAL is a multi-disciplinary open access archive for the deposit and dissemination of scientific research documents, whether they are published or not. The documents may come from teaching and research institutions in France or abroad, or from public or private research centers.
L'archive ouverte pluridisciplinaire HAL, est destinée au dépôt et à la diffusion de documents scientifiques de niveau recherche, publiés ou non, émanant des établissements d'enseignement et de recherche français ou étrangers, des laboratoires publics ou privés. 
Effect of testing conditions and doping on superplastic creep of alumina

P. Gruffel, P. Carry and A. Mocellin E.P.F.L., Lab. de ceramique

34 chemin de Bellerive, $\mathrm{CH}-1007$ Lausanne

In recent years, large tensile and compressive strains have been achieved on many fine grained ceramics materials [1-2]. Their general behaviors (temperature, grain size, stress exponents and strain rate,...) can be characterised as superplastic according to the definition of metallurgists. Recently, we have done an extensive study of fine grained $(1 \mu \mathrm{m}) \mathrm{Mg} 0$ doped alumina by com. pressive creep tests at $1450{ }^{\circ} \mathrm{C}$ [3]. It was unambiguously established that:

- normal grain growth took place concurrently with deformation, leading to continuously decreasing strain rates.

- the constant applied stress does not influence the time exponent in the grain growth kinetic 1 aw but enhances the rate constant.

- cavitation occurs at grain triple junctions due to extensive grain boundary sliding.

- some crystallographic texture evolutions have been observed even at low stress levels (10 $\mathrm{MPa}$ ) which cannot be explained by basal glide.

The behavior of alumina appears very similar to that of metallic systems at the macroscopic level (stress exponents,...) as well as with respect to microstructural evolutions. It may be considered as a model system to study the grain-boundary behaviors which determine the structural evolution during superplastic deformation.

$\sigma=20 \mathrm{MPa} \quad \mathrm{T}=1450^{\circ} \mathrm{C}$

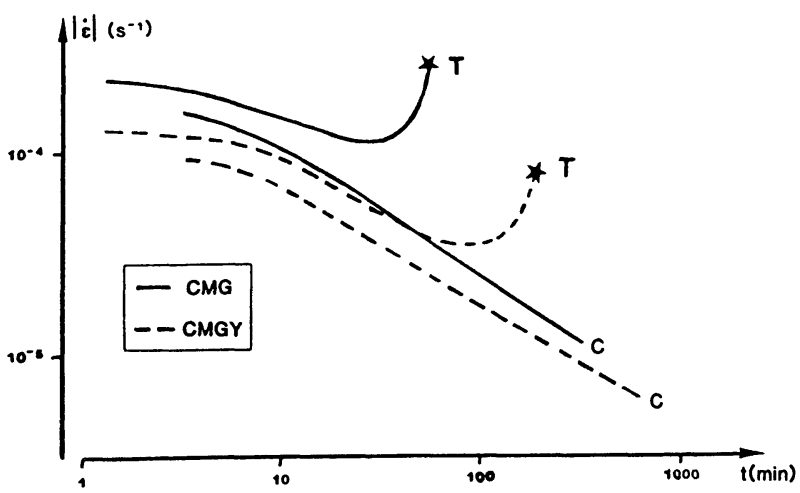

Fig. 1. Strain rate variations during creep tests in compression $\mathrm{C}$ and tension $\mathrm{T}$ for $\mathrm{Mg}$ doped (CMG) and $Y$ co-doped (CMGY) alumina with respectively $0.8 \mu \mathrm{m}$ and $0.66 \mu \mathrm{m}$ inital grain sizes.

In this context we present here some prel iminary results on direct comparison between compression and tensile behaviors of MgO doped alumina and with two kinds of additional doping elements $\left(\mathrm{Y}_{2} \mathrm{O}_{3} 500 \mathrm{ppm}\right.$ and $\mathrm{Ti}_{2} \mathrm{O}_{3} 1 \%$ we ight $)$. Tests have been performed in creep conditions under constant stresses. At $1450^{\circ} \mathrm{C}$ under $20 \mathrm{MPa}$ elongations to

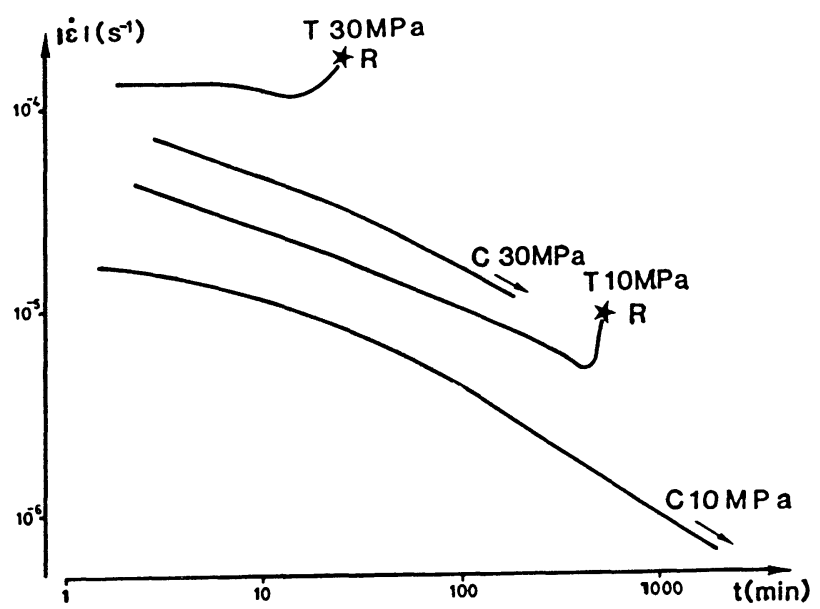

Fig. 2 Strain rate vesus time for compressive $C$ and tensile $\mathrm{T}$ tests at $1250{ }^{\circ} \mathrm{C}$ on $\mathrm{Ti}$ doped alumina (inital grain size $0.7 \mu \mathrm{m}$ ).

rupture up to $65 \%$ (0.5 true strain) have been observed on $\mathrm{Y}_{2} \mathrm{O}_{3}$ doped alumina. In tension, strain rates begin to decrease as in compression, likely due to concurrent grain growth (Fig. 1) and are higher in tension than in compression ( $f$ actor 1.5 to 2) as soon as the test begins. At $1250^{\circ} \mathrm{C}$ for the $\mathrm{Ti}$ co-doped alumina the behavior is similar (Fig. 2) and strain rates differ by a factor of 4 between tension and compression but failure occurs after only $30 \%$ elongation. The rupture in tension occurs by catastrophic propagation of macrocracks which result from the coalescence or the linking of small equiaxed cavities. Compression tests on specimens with different equivalent diameter to height ratios $(0.37 ; 1 ; 1.4)$ have shown that tension/compression differences cannot be explained by friction effects as proposed by Wang and Raj [4] for glass ceramic materials. The strain rate differences appear all the more significant as they are observed from the very beginning of the tests. On the matter of direct comparisons between tension and compression behaviors, the litterature appears rather poor on ceramics as well as on metallic materials.

It is suggested that more systematic experimental investigations would be needed before a clear understanding and subsequent modelling of such differences in behaviors can be arrived at.

\section{REFERENCES}

[1] C. Carry and A. Mocellin, in: Superplasticity Editions du C.N.R.S. (1985) C16

[2] F. Wakai, S. Sakaguchi and Y. Matsuno, Advanced Ceramic Materials 1 (1986) 259-263.

[3] J.D. Fridez, C. Carry and A. Mocellin, in: Advances in Ceramics Vol. 10, edited by W.D. Kingery, Amer. Ceram. Soc. (1984) 741-749.

[4] J.G. Wang and R. Raj, J. Amer. Ceram. Soc. 67 (i984) 399-409. 